\title{
Small Stone Vessels
}

\author{
Virginia L. Emery
}

\section{1 \\ Object Types}

The stone vessels recovered from Cemeteries N 2000 and N 2500 continue the chronological progression of vessels from Cemeteries $\mathrm{N}_{500-900}$ that represents development from the Second Dynasty to the Sixth Dynasty, with a stylistic break at the beginning of the Fifth Dynasty (Reisner 1932, 36-75). For the most part, the vessels from Cemeteries N 2000 and N 2500 overlap with the Fifth Dynasty examples from the earlier cemeteries and display forms attested through the Sixth Dynasty and into the early First Intermediate Period (Reisner 1932, 56-70; Aston 1994, 84-85, 135-141). Vessel shapes and sizes otherwise unattested from Cemeteries $\mathrm{N}_{500}$-900 were uncovered in Cemeteries $\mathrm{N} 2000$ and $\mathrm{N} 2500$, which necessitated the addition of subcategories to Reisner's original typology $(1932,36-75)$ and suggests either that the burials from which they came were later than those in Cemeteries $\mathrm{N}_{500-900, \text { pos- }}$ sessing more burials of the Sixth Dynasty and early First Intermediate Period, or that they are the products of different workshops with, perhaps, different styles, than the assemblages from the cemeteries published by Reisner. Given the other similarities in the vessels from the earlier cemeteries, the former is more likely than the latter. A later date is also suggested by the number of burials with stone vessels, a practice that decreased through time, as is evident in the number of vessels recovered from burials of Dynasties 2-3 compared to the number from Dynasty 4 burials (Reisner 1932, 55); for Cemeteries N 2000 and $\mathrm{N} 2500$, only eight tombs contained stone vessels, seven in $\mathrm{N} 2000$ and one in $\mathrm{N} 2500$. The graves with stone vessels were of tomb types vi a-d, the Dynasty $5^{-6}$ types comprised of open pit tombs usually covered with stone slabs, but with various levels of wall finishing (Reisner 1932, 24-30, and Chapter 12 in this volume).

As with many durable goods, stone vessels are useful for dating, but represent a class of artifacts that could be handed down and are thus less securely diagnostic than ceramics (Slater 1974, 232-233), though, with the exception of footed cylindrical jars, their forms generally are related to those of contemporary ceramic and metal vessels (Reisner 1932, 68-70). Indeed, vessel forms across materials for the late Old Kingdom can be so similar that Reisner classified four 
vessels (PAHMA 6-14301, PAHMA 6-14308, PAHMA 6-14309, PAHMA 6-14418) as limestone toilet jars (O.K.x.b, early kohl jars, Reisner 1932, 65-66), which, upon closer examination, proved to be ceramic instead and are treated in this volume with that corpus. Similarly, the collared necks of the stone jars of the Fifth and Sixth Dynasties (Reisner 1932, 63-64, O.K.iv, O.K.v) are the equivalent of the recurved rims on ceramic vessels (Wodzinska 2010, 127, O.K. 18), and the body shape of those vessels and all of the tall, slender vessels mimics that of the beer jars of the same era (Wodzinska 2010, 12O-122, O.K. 1-4, 6). For the corpus of stone vessels from Cemeteries N 2000 and N 2500, many ceramic parallels date to the First Intermediate Period, suggesting a stylistic lag between popular stone and ceramic vessel shapes and would reinforce the later date of the cemeteries. The single inscribed piece (PAHMA 6-14424) bears a cartouche of Pepy I (Figure 5.6) and belongs to a class of vessels commemorating his first sed festival (Reisner 1932, 57, Type I.d Example No. 2).

As with ceramics, the shapes or forms of the stone vessels presumably were related to their contents, which in turn related to the function of the vessel. Many of the stone vessels recovered from Cemeteries N 2000 and N 2500 are of types attested as hieroglyphs (Gardiner W1-2 "Sealed oil jar"=Reisner 1932, Later Group Type I; Gardiner W6 “O.K. sign for particular vessel”=Reisner 1932, Earlier Group Type I; Gardiner W14 "tall water pot"=Reisner 1932, O.K.i.a; Gardiner W22 "beer jug"=Reisner 1932, Type v; and Gardiner W24 "bowl"=related to Reisner 1932, O.K.x [early kohl jar]) and were common for the storage of valuable goods, such as perfumes, unguents, and kohl. The potential value of the contents, together with the value of the vessels' material (stone rather than ceramic), result in valuable vessels, as evidenced by the inclusion of fragmentary vessels in several burials in Cemeteries $\mathrm{N} 2000$ and N 2500, especially fragments that clearly show reuse (PAHMA 6-14353). However, the vessels included in burials need not necessarily have contained the goods for which the vessel shape was designed (Hester and Heizer 1981, 22), given that they occasionally occur with incompletely cored interiors (i.e., Reisner 1932, 39, Fig. 5, 37-39) and given the general lack of evidence for internal residue in the corpus from Cemeteries $\mathrm{N} 2000$ and $\mathrm{N}$ 2500. Taken together, this suggests that the exterior shape alone could serve as the symbolic representation of the contents for the afterlife.

The bulk of the stone vessels from Cemeteries N 2000 and N 2500 are travertine, or Egyptian alabaster, with a preference for white or pale-yellow stone with a small crystal structure. When bands occur, the darker brown stone or clearer crystal stripes appear to have been intentionally positioned on the vessel for decorative effect, either at the neck (PAHMA 6-14351, MFA 47.1652), on the body (PAHMA 6-14421), or at the base (РАнмA 6-14421, РАнмA 6-14426). The similarity of the stone color, banding, and fine crystalline structure suggests that the raw material for most or all of the vessels was from the same 
location. The most likely source is the quarries at Hatnub, as they are known to have been in operation during the Old Kingdom (Klemm and Klemm 2010, 161-163; Aston, Harrell, and Shaw 2001, 59-6o; Aston 1994, 47-51). A deposit of travertine in the neighborhood of Assiut lay slightly closer to Naga ed-Deir, but appears not to have been operational until the New Kingdom (Klemm and Klemm 2010, 163-164). In addition to travertine vessels, there is a single example in veined limestone (РAHMA 6-14420) and a single example in what most likely is serpentinite (Harrell, personal communication). Limestone is widely available in Egypt, with deposits stretching from Cairo to Esna, providing a range of possible sources for the vessel (Aston 1994, 36-37; Aston, Harrell, and Shaw 2001, 40-42; Aston 1994, 35-39); known Old Kingdom limestone quarries in the area around Giza may have provided the material for the Naga edDeir vessel, or it may have come from a local source (Klemm and Klemm 2010, 23-139; Aston 1994, 37). Although pharaonic serpentinite quarries have proved elusive, outcrops occur in the Eastern Desert, with perhaps the most easily accessible concentrations from Naga ed-Deir being in the Wadi Hammamat (Klemm and Klemm 2010, 294-295; Aston 1994, 56-59; Aston, Harrell, and Shaw 2000, 56-57).

The vessels from Cemeteries N 2000 and N 2500 are for the most part wellexecuted, with polished exteriors and fully cored interiors. Exterior surface treatment ranges from highly polished with little visible indication of the polishing process, typical for the tall, slender vessels, to polished but with surviving striations on the surface of the vessel, more typical for the short, squat vessels. While the exteriors are universally polished, the interiors are not, retaining the striations and cuts resulting from the production process (Hester and Heizer 1981, 6-15). At best, the interior of the rims of tall, slender vessels are polished, a treatment especially common for the flared neck jars, and, in some cases, the finer of the internal striations were worn down, whether in the production process with the introduction of sand or emery or by additional polishing post-production, though the closed forms of most vessels suggest the former (Hester and Heizer 1981, 11-12). Although most examples have interiors with shoulders shaped to match the exterior, not all do, as a simple straight core would have simplified the production process significantly (Hester and Heizer 1981, 19-20).

\subsection{The Earlier Group of Stone Vessels, Dynasties 2-4}

Type I: Cylindrical Jars, used for containing perfumes, resins, and similar materials; shown on early reliefs with mouth covered with cloth or parchment, tied with string below rim and sealed on top (Reisner 1932, 36-37).

c. Forms without any indication of string; Dyn. 2-4

Example: MFA 47.1652 $\quad \mathrm{N} 2641$ 
Type v: Shoulder Jar with rim and flat base (Reisner 1932, 41)

c. (2) Wide-shouldered jars, squat form

Example: PAH MA 6-1442O N 2071

\subsection{The Later Group of Stone Vessels, Dynasties 5-6}

\section{O.K. Vessels of Older Forms:}

Type I: Cylindrical Jar, used for containing perfumes, resins, and similar materials (Reisner 1932, 56-57)

c. Without indication of string around neck

ii. Well-made forms

Examples: PAHMA 6-14386 N 2075

PAHMA 6-14417 N 2093

PAHMA 6-14424 ${ }^{1}$ N 2096

d. With exaggerated splay-foot widened into disk around base

EXamples: PAHMA 6-14369 N 2071a

\section{The New O.K. Types of Stone Vessels:}

O.K.i: Jar: flaring neck with rim, round shoulder, tapering body, and practical flat base (Reisner 1932, 61-62)

a. Larger forms; height $12-16 \mathrm{~cm}$

Examples: PAHMA 6-14419 N 2096

MFA 47.1695 N 2021

c. Medium forms; height 7-12 cm

Example: PAHMA 6-14392 N 2075

O.K.ii: Jar: flaring neck usually with rim, round shoulder, tapering body, and pointed base (or with small flat spot) (Reisner 1932, 62-63)

a. Larger forms; height $12-38 \mathrm{~cm}$

Example: MFA 47.1694 N 2021

b. Smaller forms; height 4-9 cm

Example: PAHMA 6-14422 N 2096

O.K.iii: Jar: flaring neck with rim, ovoid body, with thickest point above middle, small flat spot as base (Reisner 1932, 63)

b. Bulging body

Example: PAHMA 6-14427 N 2096

O.K.iv: Collar jar: concave collar neck, tapering body with pointed base (Reisner 1932, 63-64).

b. Bulging forms

Example: PAHMA 6-14425 N 2096

1 Reisner 1932, 57. Although Reisner classifies this vessel as one having a splay foot (his Type I.d), its base compares better to the vessels he classified as "well-made forms" (his Type I.c.ii). 
c. Oval forms

EXamples: PAHMA 6-14421 N 2096

PAHMA 6-14435 N 2103

O.K.v: Collar jar: concave collar rim, tapering body with narrow flat base (Reisner 1932, 64-65)

a. Slender forms, height $5^{-17} \mathrm{~cm}$

Examples: MFA 47.1696 N 2021

MFA 47.1697 N 2021

PAHMA 6-14342 N 2042

PAHMA 6-14423 N 2096

b. Bulging forms, height $5^{-7} \mathrm{~cm}$

Examples: PAHMA 6-14351 N 2071

PAHMA 6-14426 N 2103

O.K.ix: Bag-shaped jar with rim (no neck) (Reisner 1932, 65)

a. Curved outline of base

Examples: PAHMA 6-14432 N 2103

PAHMA 6-14433 N 2103

O.K.x: Small jar: short neck and rim, broad flat base; early kohl jar (Reisner 1932, 65-66)

b. Squat forms

Examples: PAHMA 6-14331 N 2041

PAHMA 6-14391 N 2075

PAHMA 6-14412 N 2093

c. Spherical jar, $n w$-jar

Example: PAHMA 6-14352 N 2071 (secondary)

\section{Fragments:}

$\begin{array}{ll}\text { PAHMA 6-14353 } & \text { N 2O71 } \\ \text { PAHMA 6-14354 } & \text { N 2071 }\end{array}$

\section{Stone Vessels Catalogue}

Explanation of the Stone Vessels Catalogue:

The finds' description of context below is taken from the Catalogue of Tombs. The photograph numbers reflect the original excavator's numbering system. All dimensional measurements are reported in centimeters, and all weight measurements are reported in grams.

Museum Registration: Name of object as listed on museum registration card. Typology: Reisner 1932, Aston 1994; Wodzinska 2010, where applicable. 
Material: Travertine (Egyptian alabaster), limestone, serpentinite (?).

Measurements: Height, body maximum diameter, body minimum diameter, rim diameter, rim thickness, diameter of opening, weight.

Color (with Munsell reading): White, grey, light grey, yellow, pale yellow, yellowish red, yellowish brown, brownish yellow, very pale brown, very pale light brown, pale reddish brown.

Exterior finishing: Polished or unpolished, quality of polishing (remaining tool marks), notes on surviving indications of production process.

Interior finishing: Fully or partially cored, polished or unpolished, notes on remaining indications of production process.

Internal Residue: Presence or absence, notes on contents where applicable.

All drawings of objects noted in parentheses and all diagrams of tombs can be found in the Catalogue of Tombs.

For vessels with measurements that were not applicable (N/A), entries are omitted due to space considerations.

$\mathrm{N} 2021$ Map N/A [ed.: This record is Reisner's note of preliminary work that was done in 1901.]; photos C 9628, C 9629, A 4943, B 8247. (Fig. 5.1)

Context: [ed.: According to museum records, the following objects are from this burial: MFA: 47.1694, 47.1695, 47.1696, and 47.1697.].

\section{(1) MFA 47.1694 Jar}

Flaring neck usually with rim, round shoulder, tapering body, and pointed base (or with small flat spot), larger form.

Museum Registration: Slender shouldered jar with flaring rim and pointed base. Typology: Reisner 1932, 62-63, O.K.ii.a (Dyn. 5-6); Aston 1994, 137, 127 (Dyn. 5-6); related to Wodzinska 2010, 126, OK 33 (Dyn. 6), 155 FIP 12 (FIP), and 182, MK 33 (Dyn. 11-12).

Material: Travertine (Egyptian alabaster).

Color: White (10 YR 8/1).

Height: $16.66 \mathrm{~cm}$.

Diameter (max, min): $5.728 \mathrm{~cm}, 3.321 \mathrm{~cm}$ (at based of neck); $3.5^{8} \mathrm{~cm}$ at tip of base.

Diameter (rim-external): $5.187 \mathrm{~cm}$.

Thickness (rim): $0.455 \mathrm{~cm}$.

Opening Diameter (boring hole): $2.917 \mathrm{~cm}$.

Weight: 194 g.

Exterior finishing: Polished, vertical striations surviving on body, but much polished away and very smooth; horizontal striations on neck, especially visible under rim; rim well-rounded. 
Interior finishing: $0.923 \mathrm{~cm}$ at rim of neck interior is polished; the rest of the interior remains unpolished, with horizontal striations of production process still visible, especially at base of vessel.

Internal residue: Two drips of something sticky on one side, with sand still slightly clinging to (possibly modern), otherwise clean.

Cream color alabaster, very fine grain for top $2 / 3$ of vessel, larger crystals revealed at base with tapering of vessel; one opaque spot of white on neck; vessel likely suffered post-depositional damage, as evidenced by a $6.00 \mathrm{~cm}$ and a $2.00 \mathrm{~cm}$ seam or crack positioned opposite each other on the vessel; all vessels from this tomb bear similar cracks, as if something heavy fell on them when standing in a line.

(2) MFA 47.1695 Jar

Flaring neck with rim, round shoulder, tapering body, and practical flat base, larger form.

Museum Registration: Tall shouldered jar with neck and projecting rim (hes-jar).

Typology: Reisner 1932, 61-62, O.K.i.a (Dyn. 5-6); Aston 1994, 138, 34 (оK-M K); related to Wodzinska 2010, 156, FIP 16, FIP 17.

Material: Travertine (Egyptian alabaster).

Color: White (10 YR 8/1).

Height: $12.555 \mathrm{~cm}$.

Diameter (max, min): $4.885 \mathrm{~cm}, 2.575 \mathrm{~cm}$ (base); $3.204 \mathrm{~cm}$ (base of neck).

Diameter (rim-external): $4.690 \mathrm{~cm}$.

Thickness (rim): $0.494 \mathrm{~cm}$.

Opening Diameter (boring hole): $2.771 \mathrm{~cm}$.

Weight: $127 \mathrm{~g}$.

Exterior finishing: Polished, diagonal on body (down at left, rising to right), horizontal on neck, diagonal under rim, horizontal at rim, and multi-directional across flat rim top, chevron striation at base.

Interior finishing: Unpolished, horizontal striations of production clearly visible and feelable; interior rounded at base, but close to bottom of vessel (in contrast to point of 47.1694).

Internal residue: Clean (dust only).

Broken, repaired $195^{\circ}$ by W. J. Young; cream-colored travertine, fine crystal, consistent across body, looks like ostrich egg shell when back lit; vessel cracked along length, almost, but not quite, in half, much like the fault line visible on 
47.1694, probably post-depositional; based on the crystal structure, there is a possibility that 47.1694 and 47.1695 came from the same piece of raw material.
(3) MFA 47.1696
Collar Jar

Concave collar rim, tapering body with narrow flat base.

Museum Registration: Collared Jar.

Typology: Reisner 1932, 64, O.K.v.a (Dyn. 5-6), Aston 1994, 135-136, 123 (Dyn. 5FIP); related to Wodzinska 2010, 128, OK 21 (Dyn. 4), 155, FIP 12.

Material: Travertine (Egyptian Alabaster).

Color: White (10 YR 8/1).

Height: $11.158 \mathrm{~cm}$.

Diameter (max, min): $4.907 \mathrm{~cm}, 2.105 \mathrm{~cm}$ (base); $3.018 \mathrm{~cm}$ (base of neck).

Diameter (rim-external): $3.440 \mathrm{~cm}$.

Thickness (rim): $0.443 \mathrm{~cm}$.

Opening Diameter (boring hole): $2.578 \mathrm{~cm}$.

Weight: $121 \mathrm{~g}$.

Exterior finishing: Polished, vertical striations on body, horizontal striations on neck and on body above widest diameter; multi-directional striations across top of rim and across flat base.

Interior finishing: Polished at rim $0.36 \mathrm{~cm}$ into vessel, then unpolished; horizontal striations from production process visible to base; rounded base, close to flat base of exterior.

Internal residue: Small clumps of sand on one side, near widest part of vessel and again on same side near base-suggests sitting on side and filled with sand at deposition/post-deposition.

Cream-colored travertine, fine grained to within $1.17 \mathrm{~cm}$ of base; approximately one-quarter to one-third of the body and neck is opaque white, similar to an opaque patch on the neck of 47.1694, which may suggest that the two vessels were carved from the same raw material, as might 47.1695; like 47.1694 and 47.1695, cracks or seams run opposite each other on rim and into vessel body, probably post-depositional.

\section{(4) MFA 47.1697 Collar Jar}

Concave collar rim, tapering body with narrow flat base.

Museum Registration: Collared jar.

Typology: Reisner 1932, 64-65, O.K.v.a (Dyn. 5-6), Aston 1994, 135-136, 123 (Dyn. 5-FIP); related to Wodzinska 2010, 128, OK 21 (Dyn. 4), 155, FIP 12. 
Material: Travertine (Egyptian Alabaster).

Color: Very pale brown (10 YR 8/2).

Height: $8.201 \mathrm{~cm}$.

Diameter (max, min): $2.901 \mathrm{~cm}, 0.817 \mathrm{~cm}$ (base); $2.515 \mathrm{~cm}$ (base of neck).

Diameter (rim-external): $2.75^{2} \mathrm{~cm}$.

Thickness (rim): $0.305 \mathrm{~cm}$.

Opening Diameter (boring hole): $2.110 \mathrm{~cm}$.

Weight: $49 \mathrm{~g}$.

Exterior finishing: Very polished, lower body almost perfectly smooth, horizontal striations above max diameter on body and around neck, center of flare also highly polished.

Interior finishing: Unpolished, highly striated horizontally based on production process, interior not much shaped to match exterior curvature, simply cut straight down; what little incurving there is could be accidental, based on drilling too long in one place or having trouble getting a drill bit in place.

Internal residue: Dust in deep striations of interior suggest at least filled to base of neck with dirt.

Dark cream travertine, fine laminations throughout; consistent crystal structure and color throughout body (no dark bands, no areas of larger crystals); top of body and neck may have larger crystals or may just be shape that makes the crystalline structure more pronounced.

Assemblage Comment: The four vessels from $\mathrm{N} 2021$ represent one of the larger collections of stone vessels from a single tomb, with only two tombs possessing more, though they come from a tomb where the body itself was not preserved. The vessels are similar enough in material that it is possible that at least the larger three, and most likely all four, were sourced from the same piece of stone and similar enough in style and finishing to suggest that all were produced together. All four vessels possess thin vessel walls, are highly polished, and generally display an attention to high quality production. Despite the similarities, the variety of forms might indicate that each was destined to hold a different substance, though no significant residue survives in the vessel interiors to provide a clue about what they actually contained, if anything. All are tall, slender forms designed to accommodate a covering, based on the neck shapes, and all possess ceramic parallels dating to the Old Kingdom and First Intermediate Period. 

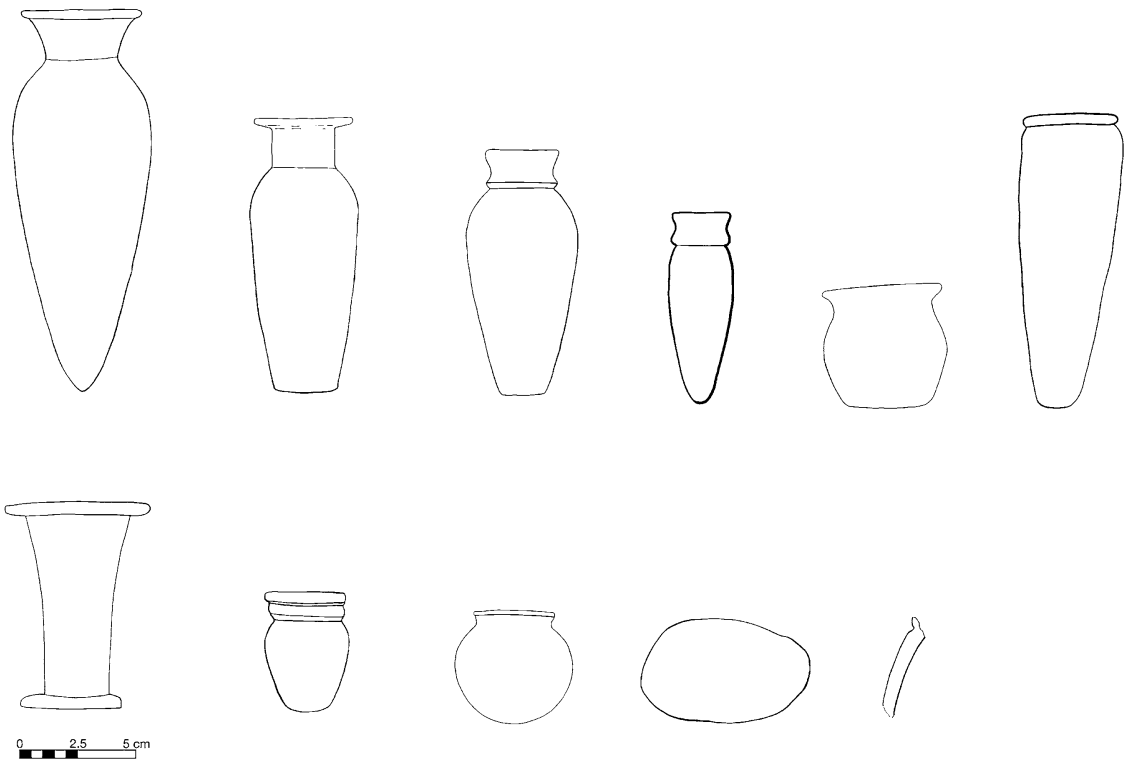

FIGURE 5.1 Stone Vessels L-R (top): Tomb N 2021: MFA 47.1694, MFA 47.1695, MFA 47.1696, and MFA 47.1697; Tomb N 2042: PAHMA 6-14331, PAHMA 6-14342; (bottom): Tomb N 2071: PAHMA 6-14369, PAHMA 6-14351, PAHMA 6-14352, PAHMA 6-14353, and PAHMA 6-14354. Drawings by author

N 2042 Map B5; type vi c; photo C 7496, C 7498, C 7499, C 7500, C 7501, C 7502, $\mathrm{C} 7503, \mathrm{C} 75 \mathrm{O} 4, \mathrm{C} 75 \mathrm{O} 5, \mathrm{~A} 8265$. (Figs. 5.1, 5.2)

Context: At /, 2 alabaster (i) (PAHMA 6-14342). At a, 1 alabaster kohl pot (PAHMA 6-14331). 2 alabaster at 8194 1/4 (iii) (PAHMA 6-14331) and 8194 2/4 (iv) (PAHMA 6-14342).

\section{(1) PAHMA 6-14331 Small Jar}

Short neck and rim, broad flat base; early kohl jar, squat form.

Museum Registration: Alabaster toilet jar.

Typology: Reisner 1932, 66, O.K.x.b (Dyn. 5-6), Aston 1994, 140-141, 140 (FIP); related to Wodzinska 2010, 152-153, FIP 3, FIP 4.

Material: Travertine (Egyptian alabaster).

Color: White (8/1 10 YR; 8/1 2.5Y).

Height: $4.595 \mathrm{~cm}$.

Diameter (max, min): $4.629 \mathrm{~cm}, 3.887 \mathrm{~cm}$ (neck).

Diameter (rim): $4.626 \mathrm{~cm}$.

Thickness (rim): $0.496 \mathrm{~cm}$.

Opening Diameter (boring hole): $3.087 \mathrm{~cm}$.

Weight: 120.o g. 
Exterior finishing: Polished, horizontal and diagonal striations just under rim exterior.

Interior finishing: None; horizontal striations of drill not smoothed out; simple core removed, shoulders not widened inside.

Internal residue: Fine black residue caught in crystal structure; not powdery; heavier deposits at base, but extends up the full interior of the vessel to the rim.

Relatively unpatterned alabaster, with $\sim 20 \mathrm{~mm}$ long crystals visible at rim; crystalline structure of alabaster very clear across base.

(2) PAH MA 6-14342 Collar Jar

Concave collar rim, tapering body with narrow flat base, slender form.

Museum Registration: Alabaster toilet jar, slender, tapering toward bottom.

Typology: Reisner 1932, 64, O.K.v.a (Dyn. 5-6), Aston 1994, 135-136, 123; related to Wodzinska 2010, 155, FIP 12.

Material: Travertine (Egyptian alabaster).

Color: White $(8 / 12.5 \mathrm{Y})$.

Height: $12.324 \mathrm{~cm}$.

Diameter (max, $\min$ ): $4.165 \mathrm{~cm}, 1.881 \mathrm{~cm}$ (base); $3.897 \mathrm{~cm}$ (neck).

Diameter (rim): $4.036 \mathrm{~cm}$.

Thickness (rim): $0.346 \mathrm{~cm}$.

Opening Diameter (boring hole): $3.042 \mathrm{~cm}$.

Weight: $182.5 \mathrm{~g}$.

Exterior finishing: Polished, but crystalline structure of stone still dominates; slight chipping at base, not repolished.

Interior finishing: Not polished, horizontal striations visible; near rim and positioned at right angles, two vertical marks, one $\sim 10 \mathrm{~mm}$ long, one $\sim 30 \mathrm{~mm}$ long, look like tool marks of chisel or something that was the starting point for the core borer; opposite side of interior smoother and thinner, no such marks visible.

Internal residue: Sand only, bottom half (and very little).

Travertine with crystalline structure that resembles fish scales with the curving of the vessel; three bands of very fine striation, alternating with two bands of larger crystals; neck shape is unusual and may be the result of cutting down a larger collared rim that broke or cracked in order to salvage the rest of the vessel.

Assemblage Comment: The two vessels found in N 2042 are a relatively standard set for the cemetery, with one shorter, squatter vessel and one taller, more slender vessel. The vessels were found together near the knees of the tomb 
owner, and the two shapes would suggest two different substances originally were contained in them. Both are made of stone displaying a marked preference for lighter travertine and are similar in their execution, lacking attention to the niceties of shape and being less polished than other stone vessels from Cemetery $\mathrm{N}$ 200o. This level of production and care might indicate that these vessels date closer to the First Intermediate Period than to the height of the Old Kingdom, a conclusion borne out by their ceramic parallels, which fall squarely in the First Intermediate Period. Unusually, the squat kohl retains vestiges of a fine black residue in the striations of the interior that is heaviest at the base, but extend all the way to the rim of the vessel; the other vessel contained only sand.

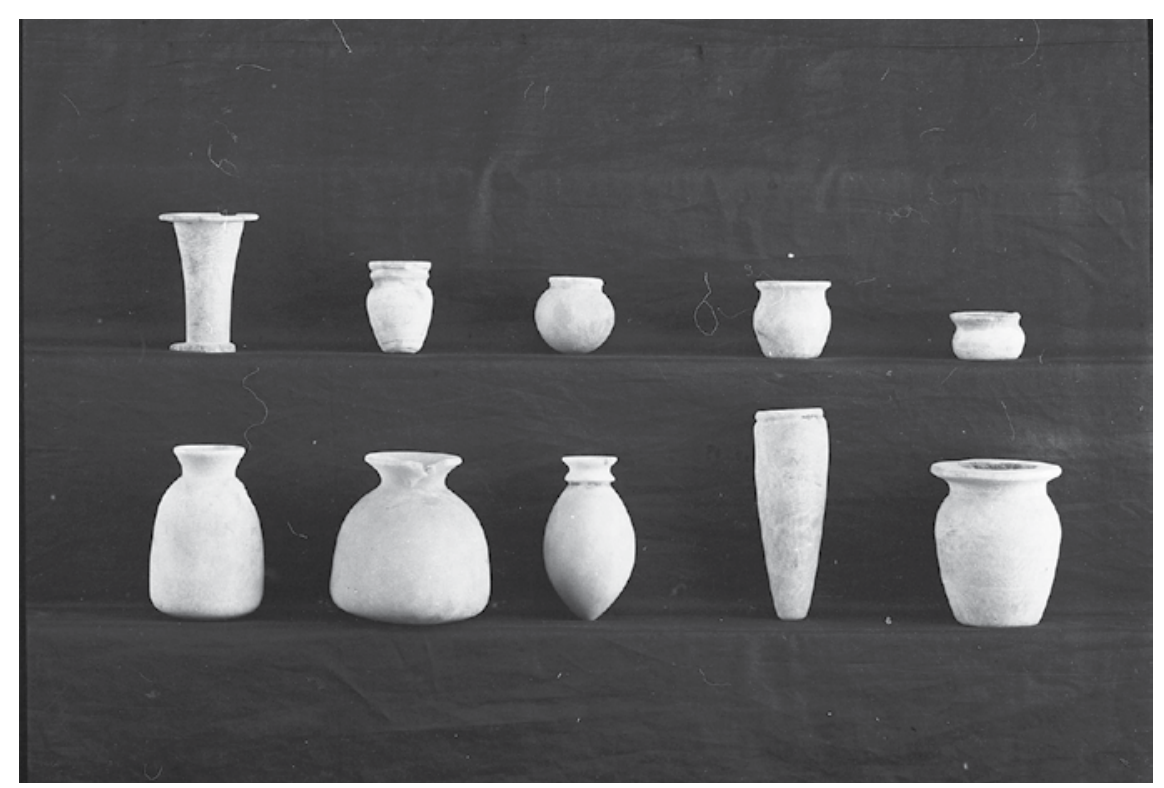

FIGURE 5.2 Stone vessels L-R (top): 6-14369, 6-14351, 6-14352 (N 2071), 6-14331 (N 2042), 6-14391 (N 2075); (bottom): 6-14432, 6-14433, 6-14435 (N 2103), 6-14342 (N 2042), 6-14392 (N 2075) (NED-C-8194)

N 2071 Map B4; type rock-cut chamber with sloping entrance; photos $C$ 8074, C 8567, A 8267, A 8268, B 825o. (Figs. 5.1, 5.2, 5.3)

Context: (b) 2 pieces of an alabaster jar, one of which had been used as a scraper (PAHMA 6-14353, PAH MA 6-14354). Alabaster at 8194:(xii) 2071a, (xiii) 2071a, (xiv) 2071: really 2093. [ed.: For the alabaster jar (xiv), see PAHMA 6-14412 in N 2093. According to Hearst Museum records, PAHMA 6-14351 and PAHMA 6-14352 are from this burial. PAHMA 6-14369 is from $\mathrm{N}$ 2071a.]. 
(1) PAHMA 6-14369 Cylindrical Jar

With exaggerated splay-foot widened into disk around base.

Museum Registration: Alabaster toilet jar, flaring rim and base broken.

Typology: Reisner 1932, 57, Type I.d (Dyn. 5-6), Aston 1994, 104, 35 (Dyn. 5-11).

Material: Travertine (Egyptian alabaster).

Color: Pale yellow (8/2 2.5Y).

Height: $8.233 \mathrm{~cm}$.

Diameter (max, min): $4.225 \mathrm{~cm}$ (neck), $2.606 \mathrm{~cm}$ (base).

Diameter (rim): $5 \cdot 975 \mathrm{~cm}$.

Thickness (rim): $0.432 \mathrm{~cm}$.

Opening Diameter (boring hole): $3.586 \mathrm{~cm}$.

Weight: $80.4 \mathrm{~g}$.

Exterior finishing: Highly polished, no striations visible except on top of footed base, where a single groove was not polished away.

Interior finishing: Top half of vessel interior polished, bottom half retains horizontal striations with four visibly larger grooves on sides and at base.

Internal residue: Little, dark sand at bottom only.

Cream colored travertine with fine white lines on top half of vessel and very fine white lines in alabaster on bottom half of vessel, separated by a band of larger-crystaled, clearer colored stone, pretty obviously exploited as decorative, given its position on the vessel (especially visible when backlit).

(2) PAHMA 6-14351 Collar Jar

Concave collar rim, tapering body with narrow flat base, bulging form.

Museum Registration: Alabaster toilet jar, bulging at shoulder, rim chipped.

Typology: Reisner 1932, 65, O.K.v.b (Dyn. 5-6), Aston 1994, 135-136, 125 (Dyn. 5FIP); related to Wodzinska 2010, 156, FIP 16-17.

Material: Travertine (Egyptian Alabaster).

Color: White (8/1 10 YR).

Height: $5 \cdot 45^{2} \mathrm{~cm}$.

Diameter (max, min): $3.938 \mathrm{~cm}, 3.528 \mathrm{~cm}$ (neck).

Diameter (rim): $4.018 \mathrm{~cm}$.

Thickness (rim): $0.463 \mathrm{~cm}$.

Opening Diameter (boring hole): $2.514 \mathrm{~cm}$.

Weight: $81.2 \mathrm{~g}$.

Exterior finishing: Polished, scattered islands of diagonal striations still visible, along with horizontal striations around the indentations of the neck; flaw in stone at base of vessel created fine line, not smoothed down or polished off. 
Interior finishing: Simple core, no shoulders added to follow external profile of vessel; horizontal striations, most visible in bottom half of vessel, top half of vessel has been smoothed.

Internal residue: Very little sand in bottom third.

Neck of vessel more angular than other examples of collared jars; fine striations visible in the alabaster; three bands of clearer crystals in top half of vessel have been exploited to coincide with the concave part of the neck and the transition at the base of the neck for decorative purposes (most visible when backlit).

(3) PAHMA 6-14352 Spherical Jar, $n w$-jar

Museum Registration: Alabaster jar, globose, rim chipped.

Typology: unattested Reisner 1932, extend typology to include O.K.x.c., Aston 1994, 137, 131 (Dyn. 5-8) and 141, 142 (M K); related to Wodzinska 2010, 160, FIP 31 .

Material: Travertine (Egyptian alabaster).

Color: Very pale brown $(8 / 22.5 \mathrm{Y})$.

Height: $4.405 \mathrm{~cm}$.

Diameter (max, $\min ): 4.815 \mathrm{~cm}, 3.161 \mathrm{~cm}$.

Diameter (rim): $3.222 \mathrm{~cm}$.

Thickness (rim): $0.392 \mathrm{~cm}$.

Opening Diameter (boring hole): $2.676 \mathrm{~cm}$.

Weight: $100.2 \mathrm{~g}$.

Exterior finishing: Polished, base more polished that top half of exterior, and top of vessel more polished that equator; rim slightly chipped and not re-polished. Interior finishing: Simple core, shoulders not cut to match exterior profile of vessel; horizontal striations visible from base to rim, four deep grooves irregularly spaced in very base of interior.

Internal residue: Very clean, only some sand in grooves at base.

The spherical form of this vessel is otherwise unattested at Naga ed-Deir and suggests a later date for its production because the best parallels date to the First Intermediate Period and Middle Kingdom; uniform cream color alabaster with two white patches; very fine internal lines from crystalline structure.

(4) PAHMA 6-14353 Fragment, Jar

Museum Registration: Alabaster jar fragment.

Material: Travertine (Egyptian alabaster).

Color: White (8/1 2.5 YR).

Diameter (max, min): $7.453 \mathrm{~cm}$ (length), $4.669 \mathrm{~cm}$ (width). 
Thickness (body): $0.347 \mathrm{~cm}$.

Weight: $28.5 \mathrm{~g}$.

Exterior finishing: Polished-originally well-polished; broken fragment appears to have been reused, $\sim 80 \%$ of edge re-sanded (no crystalline structure visible), external surface scratched, in opposing diagonals, three patches of original surface survive, two positioned such that it may have been used as a scoop with two fingers protecting the original polish and one placed on the inside as a balance; opposing diagonals run with angle of curve, meeting at break point.

Interior finishing: Horizontal striations, two especially deep grooves probably indicate original base (transition of angle from body to base); re-polished edges particularly noticeable, with one section of edge polished at a double angle. Internal residue: None.

Edges of fragment worn or repolished, suggesting reuse of broken vessel; curve of surviving fragment suggests original diameter of approximately $10 \mathrm{~cm}$, which would indicate either a bowl, which is a form otherwise unattested for stone vessels in Cemetery N 2000 and therefore very unlikely, or a large, squat jar of a size attested only for Dynasties 3 and 4 at Naga ed-Deir (Reisner 1932, 41-42, Earlier Group Type v.c.(2) [Dyn. 2-4]), which would explain the apparent repurposing; cream color travertine, very consistent, no crystal structure visible (therefore fine crystalline structure).

(5) PAH MA 6-14354 Fragment, Jar

Museum Registration: Alabaster jar fragment. Typology: N/A.

Material: Travertine (Egyptian alabaster).

Color: Pale yellow (8/2 2.5 Y).

Diameter: $59.18 \mathrm{~cm}$ (length).

Thickness (body; max, min): $0.455 \mathrm{~cm} ; 0.178 \mathrm{~cm}$.

Weight: $16.7 \mathrm{~g}$.

Exterior finishing: Polished, horizontal striations at string line.

Interior finishing: Polished, vessel thins from string line (max thickness) down body (min thickness), which may have led to break along natural fault in stone. Internal residue: None.

Cream color, fine crystalline structure; white stripes at body curve transition (diagonal to string line); breaks all fresh, not repolished, which indicates that the fragment was not actively reused, leaving open the reason(s) behind its inclusion in the burial; curve of surviving piece suggests an approximately $6 \mathrm{~cm}$ vessel diameter, but not reconstructed from a rim or a base, so tentative. 
Assemblage Comments: This tomb with its multiple burials includes five stone vessels or fragments of vessels, more than all but one other tomb in Cemeteries $\mathrm{N} 2000$ and $\mathrm{N} 2500$, but, in most cases, it remains unclear which vessel(s) belong to which burial. Where the position of the vessels in the tomb were noted, they lay near the heads of those buried in the tomb. All vessels display the preference for light colored travertine, but apparently from different sources or deposits, given the banding on some pieces and the consistency of fabric on others. As is the case for other tombs, the mix of forms - cylindrical, bulging collared jar, and spherical jar - suggests a range of contents included in the burials, though no residue to indicate contents survives. The cylindrical jar and the collared jar both display bands of clear crystal positioned decoratively on the vessel, demonstrating attention to aesthetic considerations and possibly suggesting that the two were produced together. Unlike other tombs, this assemblage includes two jar fragments, an indication of the potential prestige value of stone vessels, even when incomplete; it is likely that both fragments came from jars dating to the early Old Kingdom.

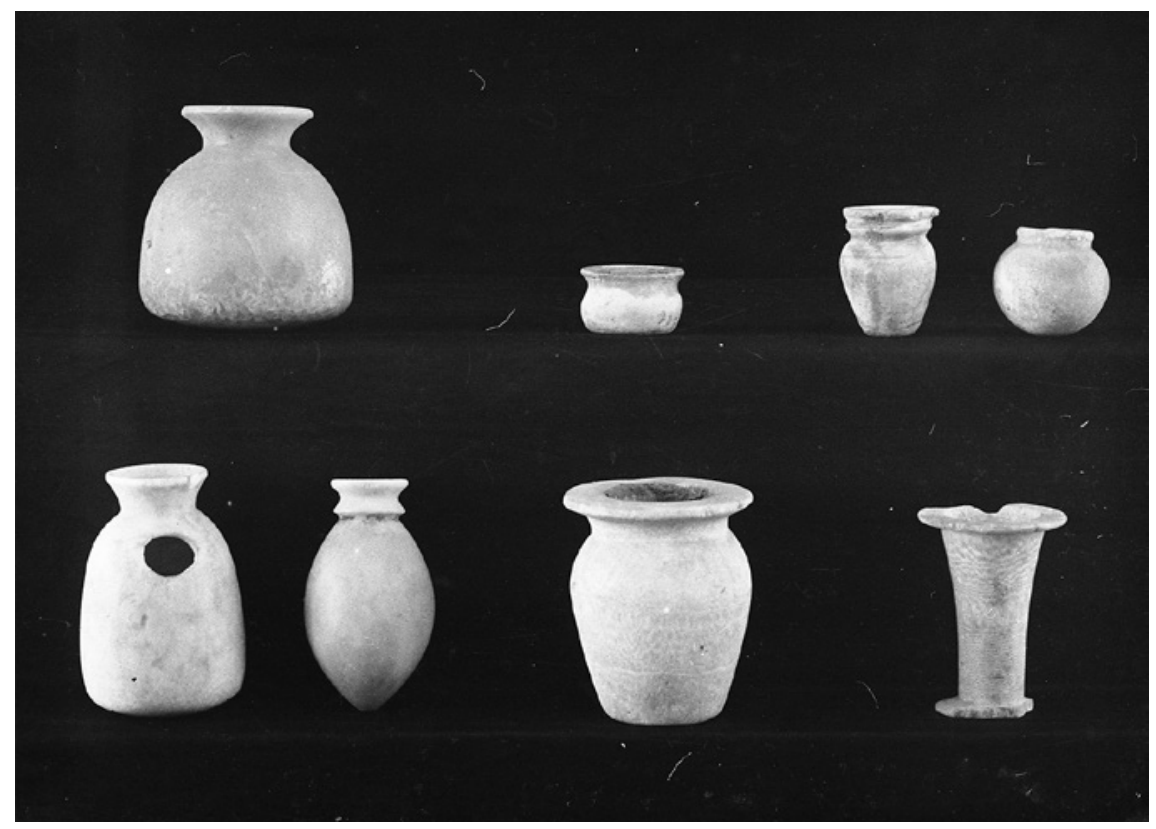

FIGURE 5.3 Stone vessels L-R (top): 6-14433 (N 2103), 6-14391 (N 2075) 6-14351, 6-14352 (N 2071); (bottom): 6-14432, 6-14435 (N 2103), 6-14392 (N 2075), 6-14369 (N 2071) (NED-C-8O74) 
N 2075 Map A4; type vi d; photo C 8074, C 8194, B 8248. (Figs. 5.2, 5.3, 5.4)

Context: In main chamber, 2 alabaster C 8194 1/5 (iv) and 2/5 (v) [ed.: According to Hearst Museum records, PAHмA 6-14386, PAHмA 6-14391, and PAHMA 6-14392 are from this burial.].

(1) PAнм A 6-14386 Fragment, Cylindrical Jar Fragment

Without indication of string around neck, well-made forms.

Museum Registration: Alabaster toilet jar rim fragment.

Typology: Reisner 1932, 56-57, Type I.c.ii (Dyn. 5-6), Aston 1994, 104, 35 (Dyn. 5-11).

Material: Travertine (Egyptian Alabaster).

Color: White (10 YR 8/1).

Height: $1.690 \mathrm{~cm}$.

Diameter: $1.581 \mathrm{~cm}$ (width of fragment taken at the neck).

Thickness (rim): $0.300 \mathrm{~cm}$.

Weight: $1.7 \mathrm{~g}$.

Exterior finishing: Polished, looks like final, finishing polish was vertical.

Interior finishing: Rim very polished, but rest of interior striated, horizontal to vessel.

Internal residue: Well encrusted with sand, both sides, hence post-depositional.

Very small fragment of very small vessel; very fine white lines of crystal formation on surviving portion.

(2) PAHMA 6-14391 Small Jar

Short neck and rim, broad flat base; early kohl jar, squat form.

Museum Registration: Alabaster Toilet Jar, squat.

Typology: Reisner 1932, 66, O.K.x.b (Dyn. 5-6), Aston 1994, 140, 140 (Dyn. 7-12); related to Wodzinska 2010, 152-153, FIP 3, FIP 4.

Material: Travertine (Egyptian Alabaster).

Color: White (8/1 10 YR) body with bands at neck and base in pink (7/3 7.5 YR).

Height: $2.840 \mathrm{~cm}$.

Diameter (max, $\min ): 4.286 \mathrm{~cm}, 3.912 \mathrm{~cm}$ (neck).

Diameter (rim-external): $4.326 \mathrm{~cm}$.

Thickness (rim; max, $\min$ ): $0.960 \mathrm{~cm}, 0.528 \mathrm{~cm}$.

Opening Diameter (boring hole): $2.655 \mathrm{~cm}$.

Weight: $70.6 \mathrm{~g}$.

Exterior finishing: Polished, natural irregularities near base of vessel not polished away; shape of vessel irregular (lopsided), but smooth throughout. 
Interior finishing: Simple core, but not that much space left for shoulder shaping inside; horizontal bands still visible, with two deeper grooves, one halfway up and one at transition from body to base.

Internal residue: Sand, light, looser, larger grained.

Vessel overall not well formed or finished; cream alabaster with very fine white lines for most of body; rim and base darker, pinker material; clearer section approximately $0.7 \mathrm{~cm}$ wide under rim on about half of vessel.

\section{(3) PAHMA 6-14392 Jar}

Flaring neck with rim, round shoulder, tapering body, and practical flat base, medium height.

Museum Registration: Alabaster jar; bulging, flat rim broken.

Typology: Reisner 1932, 61-62, O.K.i.c (Dyn. 5-6), Aston 1994, 138-139, 134-135 (Dyn. 1-12); related to Wodzinska 2010, 156, FIP 16-17.

Material: Travertine (Egyptian alabaster).

Color: White (8/1 10 YR).

Height: $9.230 \mathrm{~cm}$.

Diameter (max, $\min ): 7.212 \mathrm{~cm}, 5.727 \mathrm{~cm}$ (neck).

Diameter (rim): $7.464 \mathrm{~cm}$.

Thickness (rim): $0.722 \mathrm{~cm}$.

Opening Diameter (boring hole): $4.275 \mathrm{~cm}$.

Weight: $547.1 \mathrm{~g}$.

Exterior finishing: Polished, but with diagonal striations from polishing process around neck and very visible under rim; under rim area clearly polished in sections by something that left straight lines, with striations overlapping where turned and polished more; irregular striations also on shoulder as byproduct of neck polishing; natural irregularities in the stone at base not polished down fully.

Interior finishing: Simple core, shoulders not extended to match external profile; horizontal striations with narrowing just below halfway point, then widening again about $2 \mathrm{~cm}$ up from base, likely from drill instability.

Internal residue: A lot of light, large grained, very compact sand.

Central portion of body in white alabaster with very fine lines; two darker bands positioned horizontally on body, one-third and two-thirds of the way down the body of the vessel, seemingly with decorative intent.

Assemblage Comments: The two complete vessels in this tomb are a standard set of one short and one tall, with the addition of a cylindrical jar rim that shows no reworking. The early kohl jar form was found near the head of the 
tomb owner, and the tall, slender jar was found in a separate part of the tomb; no note was made of the original location of the jar fragment. The banding of the raw material was used to decorative effect at transitional points for the two complete vessels, which were made of similar stone and with similar production style, both being slightly irregularly shaped and neither being highly polished. The fragment of cylindrical jar was more highly polished and more finely worked than the two complete vessels, suggesting it was the product of a different hand. None of the three preserved internal residue to indicate original contents.
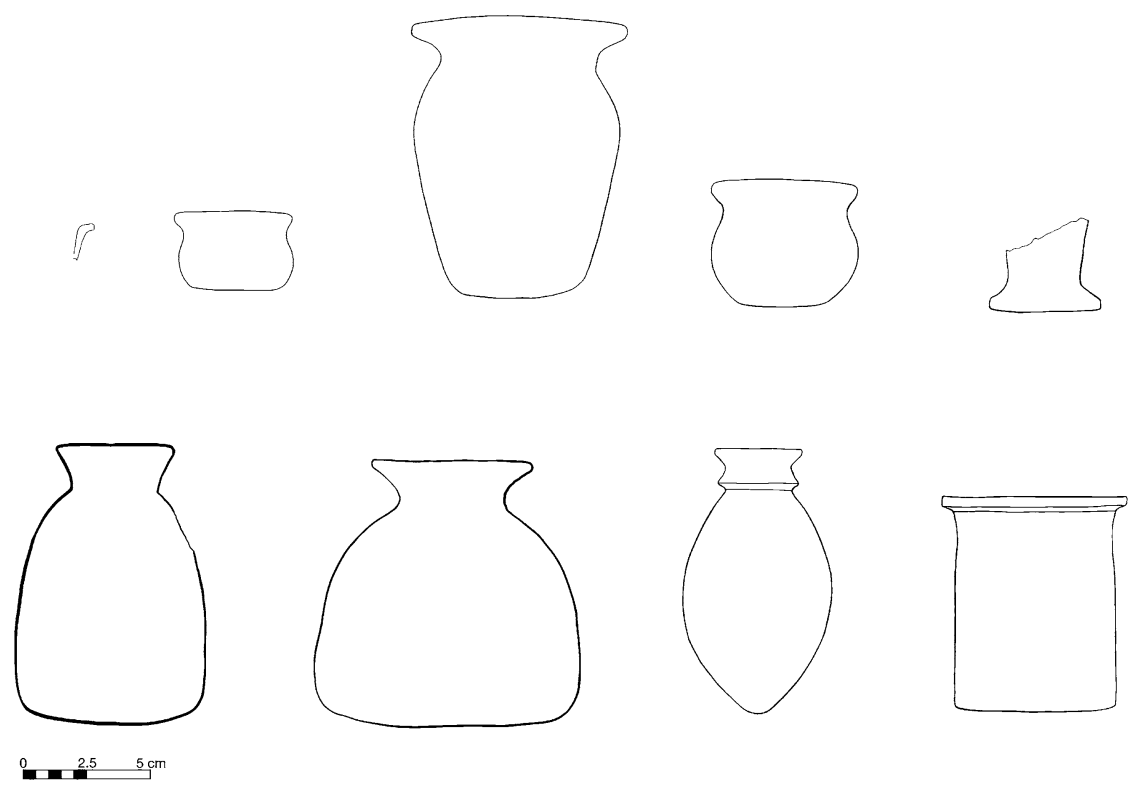

FIGURE 5.4 Stone Vessels L-R (top): Tomb N 2075: PAHMA 6-14386, PAHMA 6-14391, PAHMA 6-14392; Tomb N 2O93: PAHMA 6-14412, PAHMA 6-14417; (bottom) Tomb N 2103: PAHMA 6-14432, PAHMA 6-14433, PAHMA 6-14435; Tomb N 2641: MFA 47.1652. Drawings by author.

N 2093 Map C5; photo B 7129. (Fig. 5.4)

Context: In large chamber, broken stem of an alabaster vase (PAHMA 6-14417). Small alabaster (iv) (PAHMA 6-14412). [ed.: For a drawing of PAHMA 6-14412, see image (xiv) in $\mathrm{N}$ 2071.].

(1) PAHMA 6-14412 Small Jar

Short neck and rim, broad flat base; early kohl jar, squat form.

Museum Registration: Alabaster toilet jar, squat, flat rim. 
Typology: Reisner 1932, 66, O.K.x.b (Dyn. 5-6), Aston 1994, 140, 140 (Dyn. 7-12); related to Wodzinska 2010, 152-152, FIP 3, 4, and 16o, FIP 30, 31.

Material: Travertine (Egyptian Alabaster).

Color: Very pale brown (8/2 10 YR) body, with patch of light reddish brown (6/4 10 YR) at rim.

Height: $4.5 \circ 3 \mathrm{~cm}$.

Diameter (max, min): $5.487 \mathrm{~cm}, 4.586 \mathrm{~cm}$.

Diameter (rim): $5.304 \mathrm{~cm}$.

Thickness (rim; max, min): $1.035 \mathrm{~cm}, 0.905 \mathrm{~cm}$.

Opening Diameter (boring hole): $3.583 \mathrm{~cm}$.

Weight: $163.9 \mathrm{~g}$.

Exterior finishing: Polished, body smooth, horizontal rubbing marks around neck (top and bottom); some degradation of stone at base, hard to tell if original or post-deposition.

Interior finishing: Simple core, shoulders not shaped to follow external profile; narrows to rounded base inside; horizontal striations visible, some signs of polishing away finer striations, but deeper grooves still remain.

Internal residue: Sand, light, larger grain, mostly at base; not much on sides because a bit more polished.

Cream color alabaster with little variation; flaws in bottom of vessel and irregularity of darker color (not banded) suggest stone not the best quality; vessel generally irregular (rim, interior) and not highly finished; similar in style of craftsmanship to PAHMA 6-14391.

(2) PAHMA 6-14417 Cylindrical Jar

Without indication of string around neck, well-made forms.

Museum Registration: Alabaster jar fragment.

Typology: Reisner 1932, 56-57, Type I.c.ii (Dyn. 5-6), Aston 1994, 104, 34 (slender, Dyn. 5-6).

Material: Travertine (Egyptian alabaster).

Color: Very pale light brown (8/2 10 YR).

Height (surviving): $3.755 \mathrm{~cm}$.

Diameter (max, min): $3.140 \mathrm{~cm}$ (top); $4.390 \mathrm{~cm}$ (foot), $2.891 \mathrm{~cm}$ (above base).

Thickness (body; max, $\min$ ): $0.598 \mathrm{~cm}, 0.293 \mathrm{~cm}$.

Weight: $55.0 \mathrm{~g}$.

Exterior finishing: Polished, fine striation from polishing at foot on one side; rim of foot chipped, top break slightly rubbed down, but not fully repolished; one flatter side of foot may have been repolished. 
Interior finishing: Narrows to base, horizontal striations, with several deep grooves still visible, though it appears some care has been taken to polish away shallower striations; details rather obscured by amount of sand still encrusted on interior.

Internal residue: Light, larger grained sand, somewhat loosely packed into base.

Cream color alabaster with very fine white lines; surviving portion of vessel too thick to be very transparent.

Assemblage Comments: The two vessels from this tomb represent the standard combination of one squat and one tall, but the tall vessel is unusual for being a fragment and for being a cylindrical jar, instead of a flare or collared neck jar. Both vessels were produced from slightly cloudy stone with more crystal structure visible than other tomb assemblages. Neither is highly polished, though the early kohl jar is a more shapely and better polished version of the form than is otherwise attested in the cemetery. Both were clean inside, with loose remnants of sand the only contents.
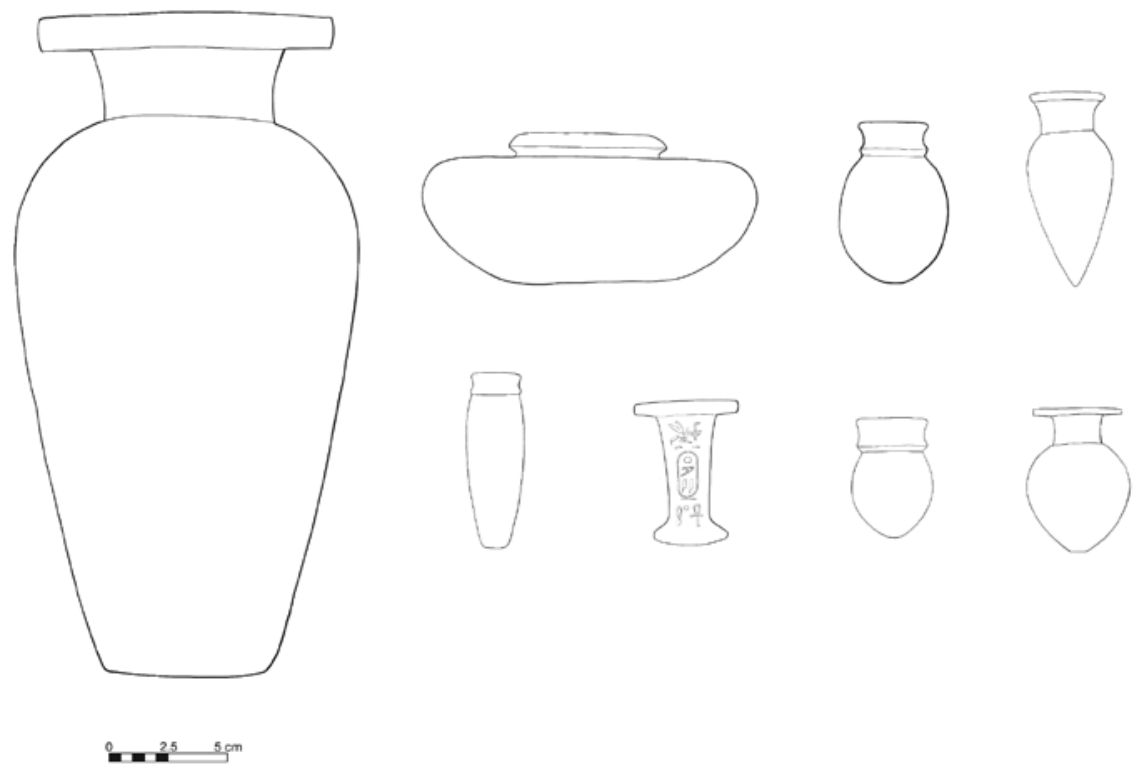

FIGURE 5.5 Stone Vessels L-R: Tomb N 2096: PAHMA 6-14419, (top): PAHMA 6-1442O, PAHMA 6-14421, PAHMA 6-14422 (bottom): PAHMA 6-14423, PAHMA 6-14424, РAHMA 6-14426, РАнмА 6-14427. Drawings by author. 
N 2096 Map C4; type vi a; photo C 2165, C 76og, C 8o67, C 8o68, C 8o69, C 8o7o, C 9630. (Figs. 5.5, 5.6, 5.7)

Context:By feet, (i) in alabaster (PAHMA 6-14419, PAHMA 6-14421, PAHMA 6-14422, PAHMA 6-14423, PAHMA 6-14424, PAHMA 6-14425, PAHMA 6-14426). (ii) in limestone? (PAHMA 6-14427) (iii) in black veined limestone (PAHMA 6-14420).

\section{(1) PAHMA 6-14419 Jar}

Flaring neck with rim, round shoulder, tapering body, and practical flat base, larger forms.

Museum Registration: Alabaster jar; bulging flat rim.

Typology: Reisner 1932, 61-62, O.K.i.a (Dyn. 5-6), Aston 1994, 138-139, 134 (Dyn. 5-6); related to Wodzinska 2010, 156, FIP 17.

Material: Travertine (Egyptian alabaster).

Color: White (8/110 YR).

Height: $23.750 \mathrm{~cm}$.

Diameter (max, $\min ): 12.200 \mathrm{~cm}, 6.226 \mathrm{~cm}$ (neck).

Diameter (rim): $11.084 \mathrm{~cm}$.

Thickness (rim): $0.810 \mathrm{~cm}$.

Opening Diameter (boring hole): $5.733 \mathrm{~cm}$.

Weight: Could not be determined (too heavy for scale).

Exterior finishing: Polished, vertical rubbing of final polish evident; some chipping at base not fully polished away, but horizontal and diagonal striations surrounding it suggest that it was original to the vessel and not post-depositional; equally, wavy lines across body, especially shoulders and on base, seem to be from flaws running through stone, not fully polished away.

Interior finishing: Shoulders shaped inside; vessel thickness apparently consistent throughout, except for one band roughly one third of the way down the body, where it appears the stone was harder; some polishing of fine grooves at very top of neck, but deeper horizontal grooves remain visible in rest of vessel. Internal residue: Reddish brown color patch on one-third of interior, base to neck, with some darker brown on shoulder only, and a clump of sand at very base; probably found tipped over on its side with sand blown in.

The finished product in the whole group of vessels that represents the finest craftsmanship as reflected in scale and finishing, including the level of polishing; largest of all vessels from Cemeteries $\mathrm{N} 2000$ and N 2500; white alabaster with larger crystals, but with two distinct bands of very fine white lines that make a decorative element one-third and two-thirds of the way down the body. 
(2) PAHMA 6-14420 Shoulder Jar

With rim and flat base, wide-shouldered jars, squat form.

Museum Registration: Limestone jar; squat marbled.

Typology: Reisner 1932, 41-42, Earlier Group Type v.c (2) (Dyn. 1-4), Aston 1994, 130, 107 (Dyn. 3-6).

Material: Limestone (veined).

Color: White (8/1 2.5 Y) and grey (5/1 2.5 Y).

Height: $5.462 \mathrm{~cm}$.

Diameter (max, $\min ): 12.173 \mathrm{~cm}, 5.413 \mathrm{~cm}$.

Diameter (rim): $5 \cdot 711 \mathrm{~cm}$.

Thickness (rim): $1.214 \mathrm{~cm}$.

Opening Diameter (boring hole): $3 \cdot 311 \mathrm{~cm}$.

Weight: $563.5 \mathrm{~g}$.

Exterior finishing: Well-polished, even under rim; some straight striations on the flat of the shoulders, clearly accommodating the neck and rim of the vessel, with the occasional finishing marks on the body; patina of darker color (10 YR 7.3 very pale brown) at base, typical of weathered limestone.

Interior finishing: Shoulders shaped to follow external profile; interior polished, though transition to base still visible.

Internal residue: Sand, light, larger grained stuff; slightly loose, not cemented.

White field with grey marbling; one side of vessel has a vein of clearer crystals running through it.

(3) PAнма 6-14421 Collar Jar

Concave collar neck, tapering body with pointed base, oval form.

Museum Registration: Alabaster toilet jar.

Typology: unattested Reisner 1932, extend typology to include O.K.iv.c (Dyn. 5-6), Aston 1994, 135-136, 124-125 (Dyn. 5-8); related to Wodzinska 2010, 155, FIP 13, 14.

Material: Travertine (Egyptian alabaster).

Color: White (10 YR 8/1) and yellowish red (5 YR 5/6).

Height: $7.050 \mathrm{~cm}$.

Diameter (max, min): $4.973 \mathrm{~cm}, 2.793 \mathrm{~cm}$.

Diameter (rim): $2.998 \mathrm{~cm}$.

Thickness (rim; max, $\min$ ): $0.364 \mathrm{~cm}, 0.23^{2} \mathrm{~cm}$.

Opening Diameter (boring hole): $2.353 \mathrm{~cm}$.

Weight: $75.8 \mathrm{~g}$. 
Exterior finishing: Well-polished, with some visible striations around neck and in collar, horizontal to indentation; multi-directional striations (including verticals) visible on body in intermittent patches.

Interior finishing: Not polished; horizontal striations remain from rim to base. Internal residue: None.

Striped alabaster, cream field with medium crystal structure visible, interrupted by two bands of darker, reddish material across shoulder, at base, and one tiny spot on rim, positioned for decorative effect.

\section{(4) PAH MA 6-14422 Jar}

Flaring neck usually with rim, round shoulder, tapering body, and pointed base (or with small flat spot), smaller form.

Museum Registration: Alabaster toilet jar, pointed bottom, flared mouth.

Typology: Reisner 1932, 63, O.K.ii.b (Dyn. 5-6), Aston 1994, 137, 127 (Dyn. 5-6); related to Wodzinska 2010, 126, Old Kingdom 16.

Material: Travertine (Egyptian alabaster).

Color: Yellow (2.5 Y 8/2).

Height: $7.961 \mathrm{~cm}$.

Diameter (max, $\min ): 3.615 \mathrm{~cm}, 2.216 \mathrm{~cm}$.

Diameter (rim): $3.080 \mathrm{~cm}$.

Thickness (rim): $0.330 \mathrm{~cm}$.

Opening Diameter (boring hole): $2.699 \mathrm{~cm}$.

Weight: $44.0 \mathrm{~g}$.

Exterior finishing: Highly polished, vertical and horizontal striations of final, finishing polish only visible on close examination; fully pointed base, no lingering flatness; light wavy lines from flaws in stone visible near base.

Interior finishing: Rim of neck polished but interior otherwise unpolished, with horizontal striations visible; shoulders shaped to match external profile, vessel appears to have same thickness throughout.

Internal residue: Little light sand, mostly clean (tag in vessel blocking part of view).

Very consistent cream-colored alabaster with very fine white lines; only one surviving oval of a whiter line to interrupt the uniformity of the stone.

(5) PAHMA 6-14423 Collar Jar

Concave collar rim, tapering body with narrow flat base, slender forms.

Museum Registration: Alabaster toilet jar. 
Typology: Reisner 1932, 64, O.K.v.a (Dyn. 5-6). Aston 1994, 135-136, 123 (Dyn. 5-8); related to Wodzinska 2010, 155, FIP 12.

Material: Travertine (Egyptian Alabaster).

Color: Pale Yellow (2.5 Y 8/2).

Height: $7.551 \mathrm{~cm}$.

Diameter (max, min): $2.632 \mathrm{~cm}, 1.240 \mathrm{~cm}$.

Diameter (rim): $2.235 \mathrm{~cm}$.

Thickness (rim): $0.257 \mathrm{~cm}$.

Opening Diameter (boring hole): $1.836 \mathrm{~cm}$.

Weight: $40.9 \mathrm{~g}$.

Exterior finishing: Well-polished, no striations on body or even around neck.

Interior finishing: Simple core with no shaping to match external vessel shape; horizontal striations from base to just shy of rim still visible; rim area polished approximately $2 \mathrm{~mm}$ into vessel.

Internal residue: Light sand, otherwise very clean.

Cream colored alabaster with very fine white lines, very consistent piece of stone; fine work.
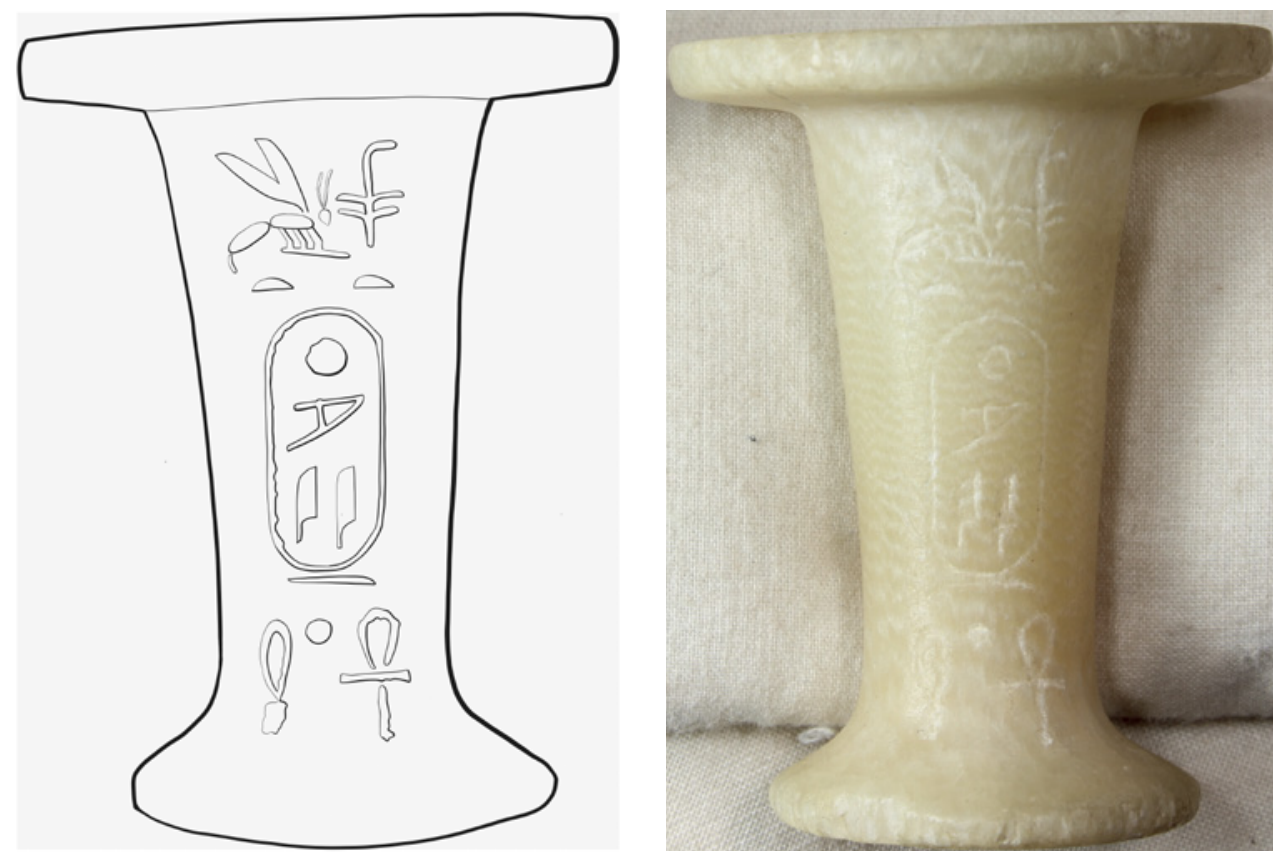

FIGURE 5.6 Inscription on 6-14424 (N 2096) 
(6) PAHMA 6-14424 Cylindrical Jar (Fig. 4)

With exaggerated splay-foot widened into disk around base.

Museum Registration: Alabaster jar, slender flat rim, cartouche on side, spreading base.

Typology: Reisner 1932, 56-57, Type I.c.ii (Dyn. 5-6), Aston 1994, 104, 35 (Dyn. $5^{-11) .}$

Material: Travertine (Egyptian alabaster).

Color: Pale yellow (2.5 Y 8/2).

Height: $6.034 \mathrm{~cm}$.

Diameter (max, min): $3.306 \mathrm{~cm}$ (foot), $1.854 \mathrm{~cm}$ (base above foot).

Diameter (rim): $4.596 \mathrm{~cm}$.

Thickness (rim): $0.446 \mathrm{~cm}$.

Opening Diameter (boring hole): $2.661 \mathrm{~cm}$.

Weight: $58.0 \mathrm{~g}$.

Exterior finishing: Well-polished body, no striations visible; visible striations around underside of rim, straight in overlapping patches to accommodate round shape of vessel; even bottom is well polished.

Interior finishing: Simple core, conical shape, matches shape of body, narrows to base; horizontal striations from base to rim, no part of rim interior polished. Internal residue: None.

Cream colored alabaster with very fine white lines; very consistent throughout vessel; lines lie horizontal to vessel body. Although Reisner classified this vessel as having a splayed foot (Reisner 1932, 57), its profile better matches the examples of his Type I.c.ii with a more gently sloping foot, as it has been categorized here and as the bulk of the other vessels in the $\mathrm{N} 2000$ and $\mathrm{N} 2500$ cemeteries are. This vessel is the only one with an inscription: the carefully etched prenomen cartouche of Pepy I (Beckerath 1999, 62-63, Dyn. 6; Reisner 1932, 57, Type I.d, Example 2), like a number of other stone vessels recovered throughout the Nile River Valley that commemorate his first sed festival (c.f. Berlin $7715 \mathrm{E}$, Louvre 527, 644, E. 3165, and E. 5356, MMA 23.10.11 and 27.2.2, OI Reg. E 10748) (Hornung and Staehelin 1974, 23-24; Strudwick 2005, 130-131).

(7) PAHMA 6-14425 Collar Jar

Concave collar neck, tapering body with pointed base, bulging form.

Museum Registration: Alabaster toilet jar, pointed bottom.

Typology: Reisner 1932, extend typology to include O.K.iv.b (Dyn. 5-6), Aston 1994, 135-136, 124 (Dyn. 5-8); related to Wodzinska 2010, 155, FIP 14.

Material: Travertine (Egyptian alabaster).

Color: White (2.5 Y 8/1). 
Height: $3.147 \mathrm{~cm}$.

Diameter (max, min): $1.911 \mathrm{~cm}, 1.582 \mathrm{~cm}$ (neck).

Diameter (rim): $1.802 \mathrm{~cm}$.

Thickness (rim): $0.238 \mathrm{~cm}$.

Opening Diameter (boring hole): $1.327 \mathrm{~cm}$.

Weight: $10.3 \mathrm{~g}$.

Exterior finishing: Polished, horizontal striations around neck, inside collar and at top of shoulders; diagonal striations on bottom half of body, clearly having to do with finishing pointed base.

Interior finishing: Simple core, interior not shaped to match exterior, perhaps due to the size of the vessel; horizontal striations from base to rim visible; no polishing around rim, which is surprisingly square in transition from interior to flat top of rim.

Internal residue: Sand, light, larger grained.

Smallest vessel of all those from Cemeteries N 2000 and N 2500, cream colored alabaster with very fine white lines; only one patch defined by white lines (as with PAHMA 6-14422); small size of vessel means stone is very consistent.

(8) PAHмA 6-14426 Collar Jar

Concave collar rim, tapering body with narrow flat base, bulging form.

Museum Registration: Alabaster toilet jar, heavy rim, pointed bottom.

Typology: Reisner 1932, 65, O.K.v.b (Dyn. 5-6), Aston 1994, 135-136, 124 (Dyn. 5-8); related to Wodzinska 2010, 155, FIP 13, 14.

Material: Travertine (Egyptian alabaster).

Color: Very pale brown (10 YR 8/2) banded with reddish yellow (5 YR 6/6).

Height: $5.264 \mathrm{~cm}$.

Diameter (max, $\min ): 3.664 \mathrm{~cm}, 2.769 \mathrm{~cm}$ (neck).

Diameter (rim): $3.177 \mathrm{~cm}$.

Thickness (rim): $0.367 \mathrm{~cm}$.

Opening Diameter (boring hole): $2.45^{2} \mathrm{~cm}$.

Weight: $56.3 \mathrm{~g}$.

Exterior finishing: Polished, horizontal striations around neck and on inside of collar; multi-directional striations on bottom half of vessel, created as pointed base was shaped.

Interior finishing: Simple core, not shaped to match exterior; horizontal striations from base to rim, with a collection of deeper grooves at very bottom; appears to be some attempt at polishing top $0.2 \mathrm{~cm}$ at transition from interior to rim, which is less square than the rim of PAHMA 6-14425.

Internal residue: Clean, faint sand in deeper grooves at base. 
Cream color alabaster with medium size crystals; band of darker, redder stone at base (for decorative effect), well defined by dark line with lighter but still redder matrix at base.

(9) PAHMA 6-14427 Jar

Flaring neck with rim, ovoid body, with thickest point above middle, small flat spot as base, bulging body.

Museum Registration: Alabaster toilet jar, globose, flat rim broken.

Typology: Reisner 1932, 63, O.K.iii.b (Dyn. 5-6), Aston 1994, 137-138, 130 (Dyn. $5^{-8)}$.

Material: Serpentinite(?).

Color: Brownish yellow (10 YR 6/6) and yellowish brown (10 YR 5/4).

Height: $5.665 \mathrm{~cm}$.

Diameter (max, min): $4.121 \mathrm{~cm}, 1.863 \mathrm{~cm}$.

Diameter (rim): $3.582 \mathrm{~cm}$.

Thickness (rim): $0.207 \mathrm{~cm}$.

Opening Diameter (boring hole): $1.764 \mathrm{~cm}$.

Weight: $34.4 \mathrm{~g}$.

Exterior finishing: Well-polished, high shine; horizontal striations visible from neck to shoulder curve; horizontal, vertical, and diagonal striations visible from shoulder curve to base; overlapping crossed striations on underside of rim.

Interior finishing: Shoulders shaped to follow external profile; horizontal and vertical striations visible in neck, interior less visible; very fine horizontal striations on visible portions of interior, without deep grooves of the travertine vessels.

Internal residue: None.

Stone is unusual for corpus, with a very fine structure based on the clean break at the rim. Shape is also unusual for corpus.

Assemblage Comments: With nine vessels, this tomb with a single individual contained the most stone vessels of any tomb in Cemetery N 2000 or N 2500, and the vessels from this tomb represent the finest examples as well, with the greatest range of shapes and materials. As noted when excavated, the vessels were positioned near the feet of the tomb owner in the burial. Seven of the nine are made of travertine, with four being consistently colored and three being banded; where banded, the form is only ovoid collared jars, and the darker bands in the stone have been decoratively positioned to fall at transition points on the bodies of the vessels. The two different types of travertine indicate different sources for the raw material and perhaps also different 
workshops producing the vessels, though all are high quality work. The cylindrical jar is the only inscribed vessel recovered from the cemetery. The material of the veined limestone squat jar is explained by its earlier date, belonging to the earlier part of the Old Kingdom when a greater variety of stone was used to make vessels. Though the shape of the serpentinite(?) vessel is consistent with those produced in the Fifth and Sixth Dynasties, the material is unusual, both for this tomb assemblage, as well as for the cemetery assemblage, the site assemblage, and, indeed, assemblages throughout the Nile River Valley. Although no early kohl jars were included in the tomb, it does possess a balanced mix of shorter, rounder vessels and taller, slender vessels, matching the general distribution of types in tombs with only two or three vessels. Despite the number of vessels in the tomb, none have anything but sand in them to indicate original contents.

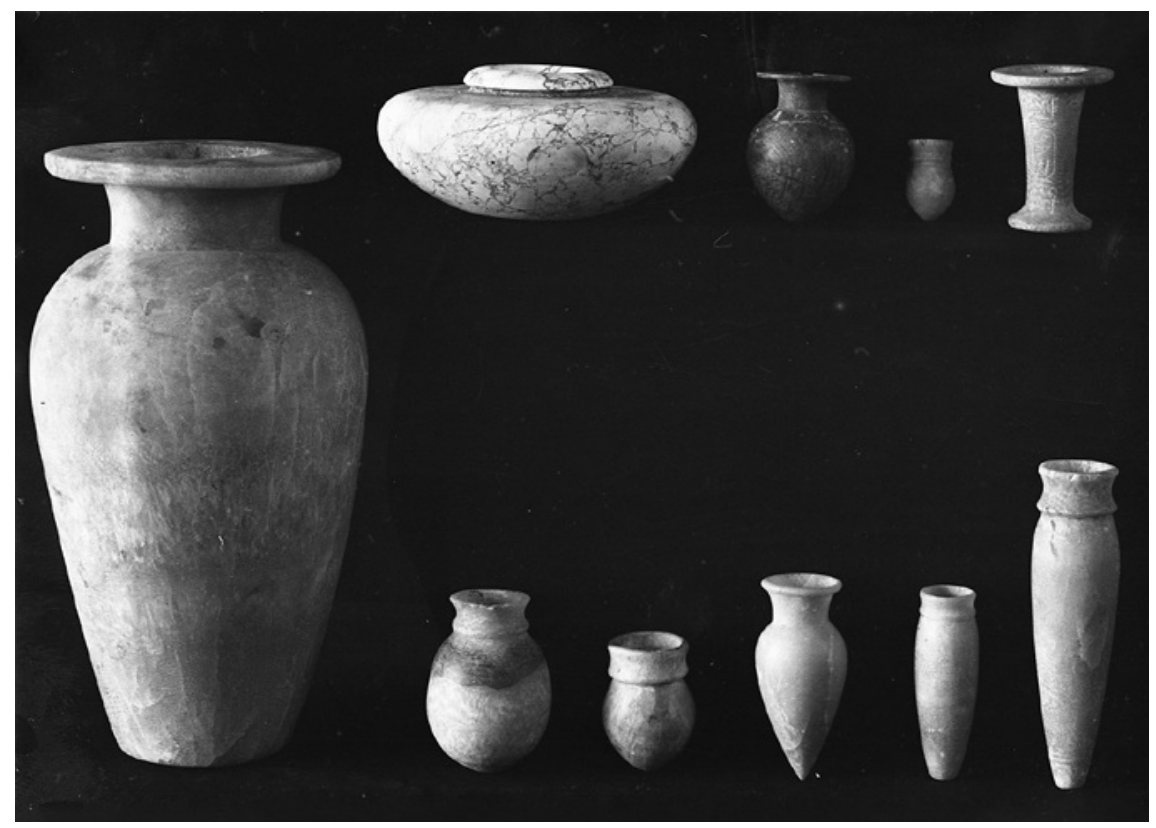

FIGURE 5.7 Stone vessels L-R 6-14419; (top): 6-14420, 6-14427, 6-14425, 6-14424; (bottom): 6-14421, 6-14426, 6-14422, 6-14423 (N 2096) (NED-C-8067)

N 2103 Map C4; type vi b; photo C 8074. (Figs. 5.2, 5.3, 5.4)

Context: 3 alabasters: (i) (PAHMA 6-14432, PAHMA 6-14433, PAHMA 6-14435).

(1) PAHMA 6-14432 Bag-shaped Jar

With rim (no neck), curved outline of base. 
Museum Registration: Alabaster jar, broadest at base, hole in side.

Typology: Reisner 1932, 65, O.K.ix.a (Dyn. 5-6), Aston 1994, 137, 128 (Dyn. 5-6); related to Wodzinska 2010, 157, FIP 2O, and 158, FIP 22.

Material: Travertine (Egyptian alabaster).

Color: White (10 YR 8/1).

Height: $9.897 \mathrm{~cm}$.

Diameter (max, $\min ): 6.689 \mathrm{~cm}, 3.073 \mathrm{~cm}$.

Diameter (rim): $4.116 \mathrm{~cm}$.

Thickness (rim): $0.283 \mathrm{~cm}$.

Opening Diameter (boring hole): $2.474 \mathrm{~cm}$.

Weight: $174.4 \mathrm{~g}$.

Exterior finishing: Polished, horizontal and diagonal striations visible across body and base; horizontal only on neck; rim slightly chipped, not re-polished; thickness of rim consistent.

Interior finishing: Shoulders shaped to match external profile; unpolished, even at rim; fine horizontal striations visible from base to rim, with one deep groove visible approximately $0.4 \mathrm{~cm}$ below rim on half of vessel neck, but no other deep grooves.

Internal residue: None.

Cream colored alabaster with very fine white lines consistently throughout; very fine stone specimen, very nicely worked and finished; same stone (and finishing) as PAHMA 6-14435; hole in vessel slightly oval, measuring $1.3 \mathrm{~cm}$ from top to bottom and $2.2 \mathrm{~cm}$ from side to side at the widest point, and positioned along the line of a natural flaw in stone that goes all the way around the vessel, which might explain the presence of the hole; some chipping around its edges, especially top left corner (exterior) and bottom edge (interior), but otherwise the edges of hole have been polished and smoothed (horizontal to the vessel body), suggesting some deliberateness in the hole or at least its repair.

(2) РАН MA 6-14433 Bag-shaped Jar

With rim (no neck), curved outline of base.

Museum Registration: Alabaster jar; broadest at base, rim chipped.

Typology: Reisner 1932, 65, O.K.ix.a (Dyn. 5-6), Aston 1994, 137, 128 (Dyn. 5-6); related to Wodzinska 2010, 157, FIP 20 and 158, FIP 22.

Material: Travertine (Egyptian alabaster).

Missing from Hearst Museum Collection, but represented in photo negative NED-C-8194 with the rest of the tomb assemblage. It has been typed and drawn based on that photo. 
(3) РАнма 6-14435 Collar Jar

Concave collar neck, tapering body with pointed base, oval form.

Museum Registration: Alabaster jar, elliptical, pointed bottom.

Typology: unattested in Reisner 1932, extend typology to include O.K.iv.c (Dyn. 5-6), Aston 1994, 135-136, 125 (Dyn. 5-8); related to Wodzinska 2010, 155, FIP 13, 14.

Material: Travertine (Egyptian alabaster).

Color: White (10 YR 8/1).

Height: $9.559 \mathrm{~cm}$.

Diameter (max, min): $5.403 \mathrm{~cm}, 2.632 \mathrm{~cm}$.

Diameter (rim): $3.216 \mathrm{~cm}$.

Thickness (rim): $0.503 \mathrm{~cm}$.

Opening Diameter (boring hole): $2.113 \mathrm{~cm}$.

Weight: $116.9 \mathrm{~g}$.

Exterior finishing: Polished, vertical and diagonal striations from base to neck, horizontal and diagonal striations visible at neck, inside collar and up to rim; one chip to rim, not repolished.

Interior finishing: Shaped to match exterior of vessel; horizontal striations from neck to base, no deeper grooves visible; top $0.4 \mathrm{~cm}$ of neck interior polished and angled to flare out.

Internal residue: None.

White alabaster with very fine white lines throughout, evenly distributed from rim to base; consistent color and pattern across vessel; looks like ostrich egg shell (including texture); similar stone and manufacture as PAHMA 6-14432 (and possibly the missing PAHмA 6-14433).

Assemblage Comments: The three vessels from this tomb represent a usual number of vessels, but an unusual group of shapes, with two bag-like forms that are unique in the cemetery. All were positioned at the feet of the tomb owner (photo C o886), and all were produced of similar material in a similar style, suggesting they were produced as a set. In addition to the unusual bagshaped vessels, the collared jar demonstrates individuality, with a more exaggerated curve to the rim than is found on other vessels of the same form. All three vessels are tall, closed forms, and thus more like the assemblage from $\mathrm{N} 2021$ than the standard mix of a balance of squat forms and tall, slender forms. All the vessels are clean inside, with no indication of original contents.

N 2641 Map C5 (red); photo B 8425. (Fig. 5.4)

Context: In main chamber, alabaster (i) (MFA 47.1652). 
(1) MFA 47.1652 Cylindrical Jar

Museum Registration: Cylindrical beaker.

Typology: Reisner 1932, 36-37, Early Group Type I.c (Dyn. 2-4), Aston 1994, 102, 31 (Dyn. 1-4); related to Wodzinska 2010, 97-99, Archaic 38, 42.

Material: Travertine (Egyptian alabaster).

Color: Munsell: White (10 YR 8/1) with light grey (10 YR 7/2) band under rim.

Height: $8.467 \mathrm{~cm}$.

Diameter (max, $\min ): 7.433 \mathrm{~cm}, 5.518 \mathrm{~cm}$.

Diameter (rim-external): 7.407-7.433 cm (ovoid).

Thickness (rim): $0.445 \mathrm{~cm}$.

Opening Diameter (boring hole): $5.866 \mathrm{~cm}$.

Weight: 232.0 g.

Exterior finishing: Polished, horizontal and diagonal striations on body, horizontal striations around base of neck and bottom of rim, diagonal striations on edge of rim, diagonal and radiant striations on top of rim; bottom of vessel, multi-directional striations.

Interior finishing: Walls of vessel relatively smooth, but not polished; $1.515 \mathrm{~cm}$ of deep horizontal striations at opening, and again approximately $0.5 \mathrm{~cm}$ from interior base of vessel, and again about halfway down sides; off-center divot in bottom of vessel where drill bit or cording of drill bit rubbed; base shows circles from production process.

Internal residue: Dust on $20 \%$ of base diameter, otherwise clean.

Cream colored alabaster with band of darker stone just under rim, with maximum thickness of $1.736 \mathrm{~cm}$; travertine with fine crystalline structure, small white lines very close together on body below darker band, on base, and on rim.

Assemblage Comments: This tomb is unique for possessing a single vessel, and a vessel whose form dates from the earlier part of the Old Kingdom at that; either the vessel was an heirloom included in a late Old Kingdom burial, or this tomb was one of the earliest in the cemetery. The cylindrical vessel is made of banded travertine, with a darker band positioned just under the rim, and was clean inside.

\section{Bibliography}

Aston, B. 1994. Ancient Egyptian Stone Vessels: Materials and Forms. Heidelberg.

Aston, B., J. Harrell, and I. Shaw. 2001. "Stone." In Ancient Egyptian Materials and Technology, edited by P. Nicholson and I. Shaw, 5-77. Cambridge. 
Beckerath, J. von. 1999. Handbuch der Ägyptischen Königsnamen. Mainz.

Hester, T. R. and R. F. Heizer. 1981. Making Stone Vases: Ethnoarchaeological Studies at an Alabaster Workshop in Upper Egypt. Malibu.

Hornung, E. and E. Staehelin. 1974. Studien zum Sedfestival. Geneva.

Klemm, R. and D. D. Klemm. 2010. Stones and Quarries in Ancient Egypt. London.

Reisner, G. A. 1932. A Provincial Cemetery of the Pyramid Age, Naga-ed-Dêr Part III. University of California Publications, Egyptian Archaeology 6. Berkeley.

Slater, R. A. 1974. The Archaeology of Dendereh in the First Intermediate Period. PhD diss. The University of Pennsylvania.

Strudwick, N. 2005. Texts of the Pyramid Age. Brill.

Wodzinska, A. 2010. A Manual of Egyptian Pottery, Volume 2: Nagada III-Middle Kingdom. Boston. 